\title{
THE MAIN PROBLEMS OF THE IMPACT OF IDEOLOGY ON THE IMPLEMENTATION OF EVIDENCE-BASED POLICY
}

\author{
Andrii Sukharyna \\ Postgraduate Student, Ivan Franko National University of Lviv; \\ Political Analyst, Ilko Kucheriv Democratic Initiatives Foundation, Ukraine \\ e-mail: andriy.sukharyna@gmail.com,orcid.org/0000-0002-9934-2291
}

\section{Summary}

The article examines the main problems that arise during the implementation of evidence-based policy. The author determines the understanding of the feasibility of evidence-based policy for high-quality policy implementation. The limitations facing the authors of the research are determined. Areas of policy research where external and ideological influence on the results obtained are highest have been identified. The author analyzes the biases of the worldview that are faced by policy researchers, and external influence that is exerted on them. The author concludes that researchers who hold different ideological views show a difference in perceptions of the world and politics. The risks faced by management bodies in the case of implementation of imperfect recommendations based on erroneous policy research are highlighted. The author notes that such risks arise from the overestimation of the ability to predict the future in political reality as scholars are exposed to the deceptive influence of research accuracy. Recommendations for improving the quality of research that become the basis for policy implementation are highlighted in the article. Arguments in favor of a more critical approach to the use of social data and the review of research results by scholars with different ideological views have been provided.

Keywords: good governance, policy research, ideology, evidence-based policy, bias, research methodology

\section{DOI: https://doi.org/10.23856/3878}

\section{Introduction}

One of the main requirements for the implementation of policy in modern democratic regimes are the evidence and rationality in its basis. The term "evidence-based policy" is widely used in the scientific literature as a definition for a policy that is implemented based on proven facts and evidence only, as opposed to emotions or subjective beliefs. This practice, arguably, is a time-consuming task for such complex systems as society, since the risks and potential threats of poor policy-making, can be catastrophic.

Today it is obvious that only such a policy and management that are based on an in-depth analysis of the situation and a scientific approach can lead to positive results of implementation and the ability of public authorities to perform their tasks. Also, this is not about some innovation or something completely unseen before. Such an approach towards policy implementation, surprisingly, came from medical science. The fact that any action that may affect an object in one way or another should not be based on personal views or preferences, but on evidence, is critical for human life. "Evidence-based medicine" was formed by experiments, trial and error, and finally proved its effectiveness. Accordingly, the effectiveness of this approach has been transferred to other areas, including policy. 
This article synthesizes studies on the main problems faced by public policy researchers that are related to several aspects: the quality and reliability of social data, ideological prejudices of scientists, as well as the impact of the external environment on research results. Based on the processed data, recommendations to improve the quality of policy research for use in public administration have been prepared.

\section{Social research data quality problems}

The specifics of social relations differ from objective reality. Politics, and relations in society, in general, are related to our attitude towards reality rather than objective reality itself. And our vision of reality, and its understanding is not always, but in fact, very rarely, reflects the real picture. In fact, our perception of reality is often more important than reality itself. In this regard, it is reasonable to provide relevant sociological studies of the Ukrainian context. According to research, the majority of the population of Ukraine is convinced that the level of corruption in the country significantly increased during 2014-2018 (Democratic Initiatives Foundation, 2018a). However, international ratings, such as the Corruption Perception Index developed by Transparency International, which measures more objective characteristics, suggests otherwise (Transparency International, 2018). Besides, according to surveys, even during the years of high economic growth, most surveyed Ukrainians were indicating that the socio-economic situation in the country has deteriorated, and such trends have been repeated throughout the whole phase of sociological monitoring (Democratic Initiatives Foundation, 2018b). If the research was based exclusively on the data of opinion polls, it could be argued that Ukraine's socio-economic situation has been steadily deteriorating for more than 20 years, which is not the case. People perceive the political state of affairs through the prism of their own ideological preferences, which significantly distort reality.

Thus, it is impossible to implement public policy relying only on public opinion data this leads to critical management mistakes and unsatisfactory results. Accordingly, opinion polls and other formats of social researches should be used very carefully.

The effectiveness of evidence-based public policy directly depends on the quality of this evidence and the data that underlie it. That is why we should strive for the highest quality level of research in political science that underpins important public decisions. The quality of political science, its verification, and provability directly affect the quality of public policy and decisions that are implemented. That is why the issue of objectivity of science itself, and political science, in particular, is relevant and widely discussed.

\section{Risks of the ideologies' influence on policy research data}

One of the main reasons why social research data may be unreliable is the assessment of the impartiality of our consciousness as well as its vulnerability to the impact of ideological and other factors. Ideology demonstrates a great challenge, because, in its essence, it is a phenomenon relevant to science.

Ideology and science are similar, primarily because of the fact, that political ideology claims to be genuine both during the process of cognition and definition, and, most importantly, during the practical transformation of reality. It can't be otherwise. In order to survive, ideology must struggle for influence on people; it must be supported by people's trust in the correctness of its ideas, to show their genuinity. Only a specific ideology can be the justest, correct, carry true, genuine values. It can solve the problems of society, provided the organization of social 
order under its requirements. This uniqueness of each ideological theory makes it close to scientific theories, if not in content, then at least in form. At the same time, if we use relativistic positions, the trend of evidence-based policy can also be called ideology, and this makes logical sense. Even the best studies of policy analysis today cannot claim to be an indisputable truth, and their full application does not guarantee the avoidance of mistakes or social problems.

In modern research, the issue of the link between ideology and science is based on an instrumental measurement of the influence of the authors' ideology on the results of their research. Research is conducted using quantitative methods, in particular on discrimination against authors with atypical political views, or the influence of authors' ideological views on the results and interpretation of their research.

There is no doubt that one or another ideology affects not only the worldview but also the behavior of people. There is some statistical evidence of this fact, including criminal activity (Wright et al., 2017: 239). American researchers analyzed the self-identification of respondents with ideological currents and compared these data with the frequency of offenses and crimes. As a result, a correlation between them was found. Based on these data, researchers argue that political ideology largely determines how people get involved in criminal activities. "Individuals self-identified as politically liberal also self-reported more involvement in crime cross-sectionally and prospectively. The relationship between political ideology and criminal conduct was linear: very conservative individuals reported the lowest levels of criminal participation and very liberal individuals reported the highest levels" (Wright et al., 2017: 239).

However, the impact of ideological beliefs on the results of the work also applies to scholars. Thus, in research from Eitan et al. (2018), empirical tests to unveil ideological "bias" in social psychology studies were conducted. According to this analysis, it was determined that the ideological preferences of scientists did influence the results of research, although this impact was much smaller than expected by the respondents themselves: "In scientific abstracts from social psychology, conservatives and conservative ideas are described significantly more negatively than liberals and liberal ideas. At the same time, conservatives are more likely to be treated as a target of explanation than are liberals. In a forecasting survey, scientists accurately anticipated the direction and general magnitude of both effects, but significantly overestimated both" (Eitan et al., 2018: 196).

However, what influences the development of the ideology of the scientists themselves? The topic of the influence of the formation of ideological beliefs through external factors, especially education, is considered. In research from Meyer (2017) that analyzes the experience of European countries, it was found that each additional year of secondary education generally correlates with the movement to the "right" in the left-right ideological dimension. It can be assumed that scholars, as the social stratum with the longest period of education and self-education, will have less inclination and commitment to socialism. However, this study does not fully take into account the real political state of affairs in the United States, where the main centers of left and socio-liberal views are in universities, and the greatest prevalence of conservative and right views dominates among people that are far from academia. Obviously, after high school, this correlation ceases to be linear and undergoes certain changes.

The issue of the impact of ideological markers on the behavior of an object is widely studied within the framework of a behavioral psychology approach. The research from Jost (2017, p. 547) summarizes the comments of a number of researchers and demonstrates the impact of ideological factors on human behavior, especially in education and science. However, it should be recognized that a person's ideology is identified by party affiliation: Democratic or Republican, which does not always demonstrate the true ideology of an individual. There were also differences in the emotional component, the specifics of political participation, social 
ties and trust in public policy. Also, the researchers' conclusions mainly relate to the fact that supporters of a certain ideology, such as conservative voters, more often act according to considerations that are correct for conservatives (Jost et al., 2018, p. 78), which can be understood intuitively. There is also evidence that conservatives and liberals perceive information differently. In particular, the study conducted by a group of scientists Oosterhoff et al. (2018, p. 230) comes to the conclusion that people with a conservative worldview more often than liberals, avoiding repulsive video scenes. There are also differences in the perception of neutral visual images. At the same time, this research does not provide information about the difference in perception of sadness or fear between people with different political views.

Other researchers are developing a theory of worldview bias. For example, Borţun (2014, p. 119) identifies five sources of cultural and ideological illusions: the technique of issue rising; the cultural paradigm; the ideological referential; the form of life; the life horizon. It is determined that these sources of illusions generate such pictures of the world, that lies in the core of the meaning of human life for specific individuals, professional groups, social classes, peoples and civilizations: "these very sources of illusion generate pictures of the world based on which individuals professional groups and social classes, peoples and civilizations render the world and human life meaningful" (Borţun, 2014: 123).

Some scholars have even proposed and tried to develop a specific "scientific ideology." And this is not about "scientific communism," but about additions to traditional epistemology and gnoseology. Such a specific scientific ideology should become part of the scientific knowledge and better defend the position of the scientific community in politics and among the general population. At the same time, researchers themselves are aware of the risks posed by such an initiative, which can have the opposite effect (Greco, 2004: 687). However, it should be noted that the scientific pursuit for the formation of "scientific ideology" for researchers, despite its contradictory nature, has repeatedly been raised by a whole list of philosophers and scientists. However, most researchers agree that in the social sciences the object of study can not be completely isolated and purified, as well as in the natural studies, the term "science" includes not only truth but also attempts to achieve that truth (Chimisso, 2015: 72).

For now, in the field of medicine and biology, the issue of the impact of ideology on scientific research is being studied the most. These are "irritating" topics such as the legalization or prohibition of certain substances and materials, the use of stem cells, the cloning of living things, or even humans (Nicholls, 2013: 143), and so on. Here, scientific research directly intersects with ethics, philosophy, and traditions that have been developed over a long period of time. In many respects, the impact of ideology on such research is crucial. It determines whether research will be conducted, what methods will be used, and so on. In fact, the implementation of public policy in these areas remains highly ideological, which affects its quality.

The situation around global warming is one of the areas where the implementation of evidence-based policies remains problematic. In this area, science often comes into conflict with ideological beliefs. Traditionally, this issue is the most acute in the United States. Because some American politicians do not believe in the effects and consequences of global warming (or deny it under pressure from the lobby of large industrial companies), this often leads to a refusal to fund such research, rejection of their results, and so on. There is a number of studies that display a correlation between the critical thinking of individuals and their beliefs about global warming (Stenhouse et al., 2018: 19).

Thus, evidence-based policy - as a global trend to improve the quality of public administration should be based on research, analytical reviews, and facts. However, it is important to remember the relativity of social knowledge. 
In his article "What is wrong with the evidence-based policy, and how can it be improved?" Saltelli and Giampietro (2017, p. 70) indicate the following:

- Policy analysis and recommendations are most often carried out by government-controlled entities, or at least by those institutions that share their ideas.

- The use of mathematical modeling and indicators conveys a spurious impression of precision, prediction, and control, which is in fact, far from reality. (Saltelli \& Giampietro, 2017: 70)

In this case, we may fall into the trap by trying to improve the quality of policy through scientific analysis, and instead only use the authority of scientific and analytical structures to promote solutions that are often far from rational. This puts us in the dangerous trap of overestimating our own ability to understand reality. It is one thing if we do not understand reality and we know about it - then our decisions will be careful and balanced, and another thing when we are sure that we know the objective picture, but in fact it is not true. In this case, we will act more decisively, but most likely incorrectly, which can lead to complex and large problems.

\section{Conclusions and suggestions}

If we analyze the situation with the regulation of science and policy research, we can see that evidence-based policy has significant problems and can not get rid of the train of ideology.

It is affected by the crisis of reproducibility of research, combined with ideological prejudices and ideological biases. It is obvious that the impact of ideology on the implementation of public policy is stronger than its influence on science itself. The public side of politics is a field where science can be seen only as one of the concepts that compete with each other, without significant advantages over traditional ideological positions.

Among the situations that negatively affect the quality of such studies, we have considered and grouped the following:

- Reliability and relevance of public data to reality;

- Ideological limitations and prejudices of scientists themselves;

- The influence of the environment and the state on research results.

In fact, public policy researchers cannot solve any of these problems on their own. At the same time, taking into account their importance in constructing the research methodology can reduce the risks of low-quality results. When using the data of public opinion polls and social research, it should be taken into account, that they do not reflect the real state of affairs, but only people's vision of it. Also, researchers are prone to ideological simplifications of reality, so it is expedient to provide peer-review of research not only within the research institution but also among colleagues with other ideological positions.

At the same time, the key conclusion is that our cognitive abilities, as well as our ability to analyze politics, are limited. We cannot be certain of the high accuracy of the predictions given the above facts. Accordingly, we need to assume that our policy research has limited accuracy and needs constant adjustment in the process of policy implementation on its basis.

\section{References}

Borţun, D. (2014). Ideological Illusions and their Cognitive Sources. Procedia-Social and Behavioral Sciences, 149, 119-128. https://doi.org/10.1016/j.sbspro.2014.08.171

Chimisso, C. (2015). Narrative and epistemology: Georges Canguilhem's concept of scientific ideology. Studies in History and Philosophy of Science Part A, 54, 64-73. https://doi.org/10.1016/j.shpsa.2015.08.016 
Eitan, O., Viganola, D., Inbar, Y., Dreber, A., Johannesson, M., Pfeiffer, T., Thau, S., \& Uhlmann, E. L. (2018). Is research in social psychology politically biased? Systematic empirical tests and a forecasting survey to address the controversy. Journal of Experimental Social Psychology, 79, 188-199. https://doi.org/10.1016/j.jesp.2018.06.004

Greco, M. (2004). The ambivalence of error: "scientific ideology" in the history of the life sciences and psychosomatic medicine. Social Science \& Medicine, 58(4), 687-696. https://doi.org/10.1016/s0277-9536(03)00220-x

Jost, J. T. (2017). Asymmetries abound: Ideological differences in emotion, partisanship, motivated reasoning, social network structure, and political trust. Journal of Consumer Psychology, 27(4), 546-553. https://doi.org/10.1016/j.jcps.2017.08.004

Jost, J. T., van der Linden, S., Panagopoulos, C., \& Hardin, C. D. (2018). Ideological asymmetries in conformity, desire for shared reality, and the spread of misinformation. Current Opinion in Psychology, 23, 77-83. https://doi.org/10.1016/j.copsyc.2018.01.003

Meyer, A. G. (2017). The impact of education on political ideology: Evidence from European compulsory education reforms. Economics of Education Review, 56, 9-23. https://doi.org/10.1016/ j.econedurev.2016.11.003

Nicholls, H. (2013). VSELs: Is Ideology Overtaking Science? Cell Stem Cell, 13(2), 143-144. https://doi.org/10.1016/j.stem.2013.07.003

Oosterhoff, B., Shook, N. J., \& Ford, C. (2018). Is that disgust I see? Political ideology and biased visual attention. Behavioural Brain Research, 336, 227-235. https://doi.org/10.1016/j. bbr.2017.09.005

Saltelli, A., \& Giampietro, M. (2017). What is wrong with evidence based policy, and how can it be improved? Futures, 91, 62-71. https://doi.org/10.1016/j.futures.2016.11.012

Stenhouse, N., Myers, T. A., Vraga, E. K., Kotcher, J. E., Beall, L., \& Maibach, E. W. (2018). The potential role of actively open-minded thinking in preventing motivated reasoning about controversial science. Journal of Environmental Psychology, 57, 17-24. https://doi.org/10.1016/j. jenvp.2018.06.001

Transparency International. (2018). Corruption Perceptions Index 2018. TI. https:// www.transparency.org/en/cpi/2018

Wright, J. P., Beaver, K. M., Morgan, M. A., \& Connolly, E. J. (2017). Political ideology predicts involvement in crime. Personality and Individual Differences, 106, 236-241. https://doi.org/10.1016/j.paid.2016.10.062

Democratic Initiatives Foundation. (2018). Otsinka problematyky koruptsii $v$ hromadskii dumtsi. [Assessment of corruption in public opinion] DIF. https://dif.org.ua/article/otsinka-problematiki-koruptsii-v-gromads. [in Ukrainian]

Democratic Initiatives Foundation. (2018). Pidsumky-2018: hromadska dumka. [Summary of 2018: public opinion] DIF. https://dif.org.ua/article/pidsumki-2018-gromadska-dumka [in Ukrainian] 